
METALS

Author(s):

\section{Submitted to:}

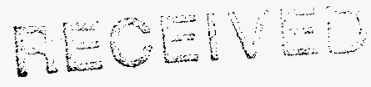

460 $29 \mathrm{ks}^{3}$

\section{$+20$}

Thomas N. Claytor, Dale G. Tuggle, and Damon D. Jackson

\section{DISCLAIMER}

This report was prepared as an account of work sponsored by an agency of the United States Government. Neither the United States Government nor any agency thereof, nor any of their employees, makes any warranty, express or implied, or assumes any legal liability or responsibility for the accuracy, completeness, or usefulness of any information, apparatus, product, or process disclosed, or represents that its use would not infringe privately owned rights. Reference herein to any specific commercial product, process, or service by trade name, trademark, manufacturer, or otherwise does not necessarily constitute or imply its endorsement, recommendation, or favoring by the United States Government or any agency thereof. The views and opinions of authors expressed herein do not necessarily state or reflect those of the United States Government or any agency thereof.

Fifth International Conference on Cold Fusion

Monaco, and Proceedings of Low Energy Nuclear Reactions

April 9-13, 1995, June 18, 1995

(Full Paper)

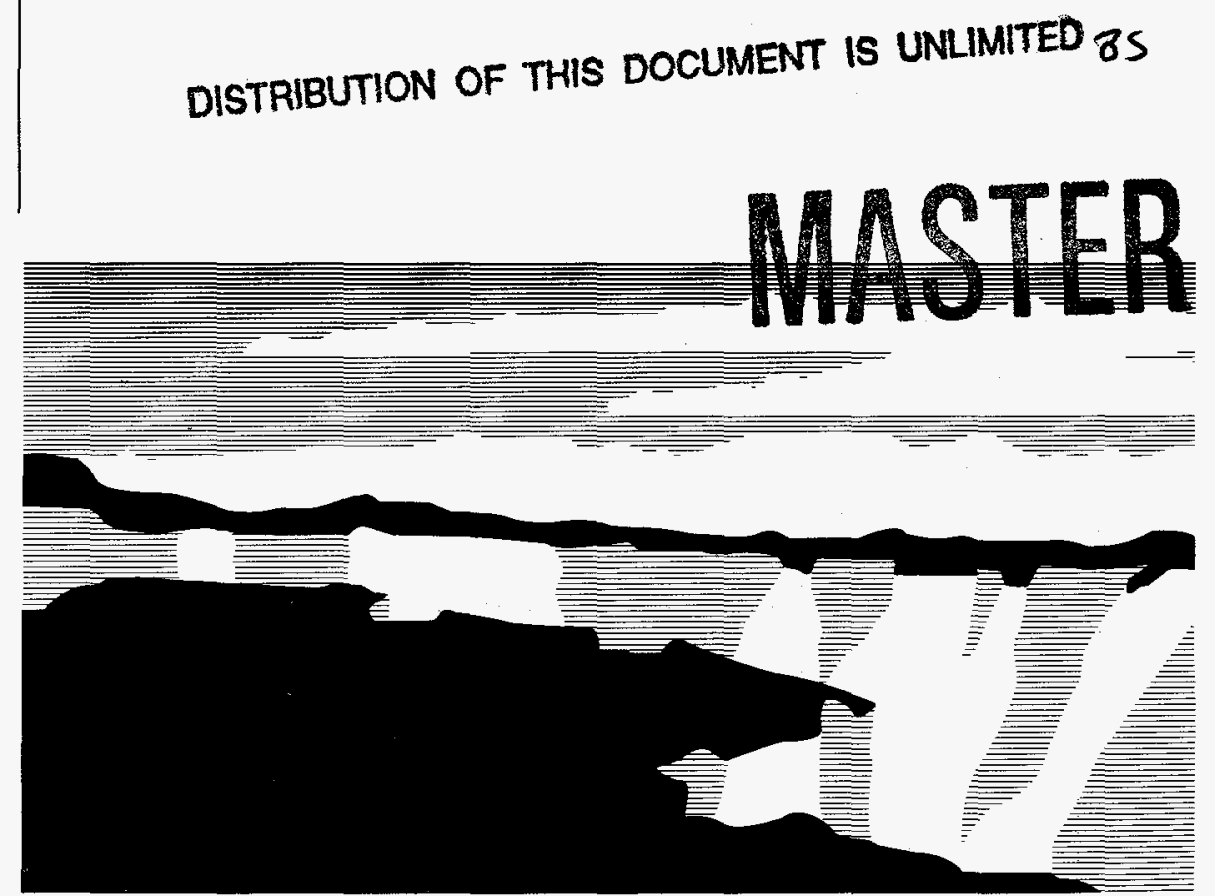

Los Alamos National Laboratory, an affirmative action/equal opportunity emplóyer, is operated by the University of California for the U.S. Department of Energy under contract W-7405-ENG-36. By acceptance of this article, the publisher recognizes that the U.S. Government retains a nonexclusive, royalty-free license to publish or reproduce the published form of this contribution, or to allow others to do so, for U.S. Government purposes. The Los Alamos National Laboratory requests that the publisher identify this article as work performed under the auspices of the U.S. Department of Energy. 


\section{DISCLAIMER}

Portions of this document may be illegible in electronic image products. Images are produced from the best available original document. 


\title{
TRITIUM PRODUCTION FROM A LOW VOLTAGE DEUTERIUM DISCHARGE ON PALLADIUM AND
} OTHER METALS

\author{
T. N. Claytor, D. D. Jackson and D. G. Tuggle \\ Los Alamos National Laboratory \\ Los Alamos, NM 87545
}

\begin{abstract}
Over the past year we have been able to demonstrate that a plasma loading method produces an exciting and unexpected amount of tritium from small palladium wires. In contrast to electrochemical hydrogen or deuterium loading of palladium, this method yields a reproducible tritium generation rate when various electrical and physical conditions are met. Small diameter wires (100-250 microns) have been used with gas pressures above 200 torr at voltages and currents of about $2000 \mathrm{~V}$ at 3-5 A. By carefully controlling the sputtering rate of the wire, runs have been extended to hundreds of hours allowing a significant amount $\left(>10^{\prime} \mathrm{s} \mathrm{nCi}\right)$ of tritium to accumulate. We will show tritium generation rates for deuterium-palladium foreground runs that are up to 25 times larger than hydrogen-palladium control experiments using materials from the same batch. We will illustrate the difference between batches of annealed palladium and as received palladium from several batches as well as the effect of other metals $(\mathrm{Pt}, \mathrm{Ni}, \mathrm{Nb}, \mathrm{Zr}, \mathrm{V}, \mathrm{W}, \mathrm{Hf})$ to demonstrate that the tritium generation rate can vary greatly from batch to batch.
\end{abstract}

\section{INTRODUCTION}

We will report on our tritium generation results from a palladium wire-plate configuration subjected to periodic pulsed deuterium or hydrogen plasma. This configuration is reproducible within a batch and produces a measurable amount of tritium in a few days. As in other work in this area, it has been found that the output is very batch dependent and sensitive to material impurities that prevent hydriding. As in our previous work ${ }^{13}$, all tritium data was obtained from several batches of 100 or 250 micron wire and 250 micron thick plate from J\&M or Goodfellow metals. In these experiments most of the tritium data was obtained with on-line tritium gas monitors. Several times, the gas was oxidized and tested with a scintillation counter.

Some have criticized the detection of tritium because the signals seem to be (a) insignificant, (b) tritium is ubiquitous, and (c) the palladium metal is subject to possible tritium contamination. The magnitude of the signals discussed in this paper are multi-sigma and are sometimes over a hundred times the tritium background in the supply gas. Furthermore, the rate of tritium evolution in the sealed system may be the most sensitive and rapid indicator of anomalous nuclear behavior in deuterided metals. As such, it is well suited for parametric investigations. We will briefly discuss the possible avenues for contamination and show that each is negligible, or not a factor, in the experiments described.

\section{MATERIALS}

For this work we used Cryogenic Rare Gases deuterium $99.995 \%$ that has $90 \mathrm{pCi} /$ of tritium, and research grade hydrogen with no detectable tritium ( $<25 \mathrm{pCi} /)$. The major impurity in the deuterium is $\mathrm{H}_{2}(0.005 \%)(\mathrm{He}<\mathrm{lppm})$. A total of $74.2 \mathrm{~g}$ of palladium wire/powder/foil was used in plasma experiments described in this paper. Of that amount, $8.6 \mathrm{~g}$ was used in various hydrogen or deuterium control experiments. The palladium has been checked for tritium contamination by two independent methods (heating in hydrogen/deuterium and $\mathrm{H}_{2}$ plasma).

Much of the palladium has been subjected to rigorous metallographic and impurity analysis. The impurity levels for the wires (Johnson Matthey Puratronic, Goodfellow) varied from the specification sheets and were in the 60$150 \mathrm{ppm}$ range (mostly $\mathrm{Cu}, \mathrm{Fe}, \mathrm{W}$ and $\mathrm{P}$ ) rather than the quoted values of 5-10 ppm. Most wires were used as received, but several wires were annealed in air (at $850^{\circ} \mathrm{C}$ for 2 hours) or stress relieved $\left(600^{\circ} \mathrm{C}\right.$. for 4 minutes) in air. Some of the wires (mostly $J \& M$ ), when wrapped on a white macor ceramic spool and heated (to $600^{\circ} \mathrm{C}$ ) left brown diffuse deposits ( $50 \mathrm{~cm}$ or more in length) or black diffuse spots (1-3 mm in length). The two batches that showed the most tritium did not yield the black spots but did leave light, small amounts of the brown deposits.

Three batches of palladium were used for the plate, the first batch of 220 micron thick foil was annealed at $850^{\circ} \mathrm{C}$ for 2 hours at $10^{-6}$ torr before use. A second batch had a different impurity analysis from the first, but was 
annealed in a similar manner, the third batch was used as received and had a different impurity level from the first two batches (although, all three plate batches had total impurities in the 350-500 ppm range, mostly $\mathrm{Pt}, \mathrm{Au}, \mathrm{Cu}$ and $\mathrm{Fe}$ ). Wire from five batches (lots W13918, W06528, Z0114, NM 35680, Z0293, GF5140/6) was obtained from Johnson Matthey and Goodfellow Metals and one length of wire was supplied by Ben Bush. Only the Goodfellow batch and J\&M (W13918) showed large ( 8 to $102 \mathrm{nCi}$ ) amounts of tritium although the other batches of J\&M and Ben Bush wire produced small amounts ( $\sim 1.5$ to $6 \mathrm{nCi}$ total per run).

Tritium contamination in the palladium wire and plate was tested by two independent methods: sputtering of the wire in a hydrogen plasma atmosphere and heating of the wire or plate to either 260 or $800^{\circ} \mathrm{C}$ in deuterium or hydrogen. No evidence of tritium (to within experimental error $\sim 0.3 \mathrm{nCi}$ ) contamination was found in the heating experiments with hydrogen. The Goodfellow wire was tested for contamination (with null results $\sim 0.3 \mathrm{nCi}$ ) by heating to $280^{\circ} \mathrm{C}$ sections $(0.1 \mathrm{~g})$ of wire taken between wire samples shown to produce tritium in the experiments. In our previous work ${ }^{3}$ we were able to set a limit of $0.005 \mathrm{nCi} / \mathrm{g}$ obtained with ${ }^{3} \mathrm{He}$ detection of aged palladium samples from a different lot. Also, in an extensive independent investigation of palladium wire, several hundred wire samples were tested and no tritium contamination was detected. The purity of the wire used in these experiments also weighs against, ubiquitous, intrinsic spot contamination, although the appearance of the black and brown deposits indicates that spot and distributed impurities can be present.

\section{APPARATUS}

Shown in Figure 1 is one of two stainless steel gas analysis loops containing a 1.8 liter ion gauge and a 310.9 cc calibration volume. The atmospheric, ion gauge and sample pressure $(0.2 \%)$; Femtotech and room temperatures $\left(0.1^{\circ} \mathrm{C}\right)$ are recorded on a computer $\log$ at $60 \mathrm{~s}$ intervals. The pressure drop during hydriding of the wire and plate is used as an approximate indicator of the stoichiometry of the $\mathrm{PdD}$. Both loops have a heater to maintain the Femtotech $(-0.03$ $\mathrm{nCi} / 1^{\circ} \mathrm{C}$ ) at a constant temperature, an integral cold trap, and there are valves that allow the pressurization of the cell independent of the loop. A two micron filter is installed at the inlet of the ion gauge and at the outlet of the cell to

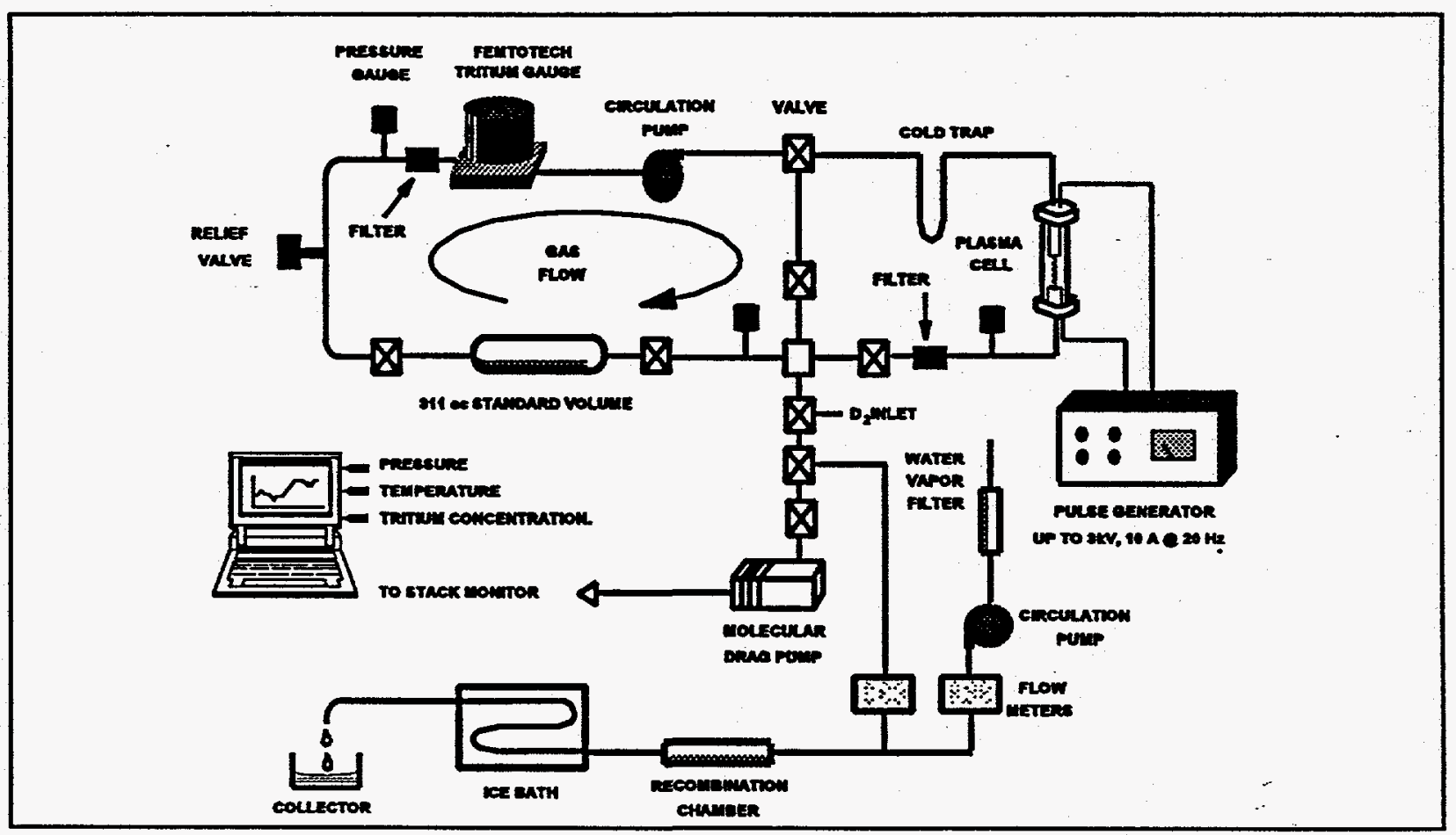

Figure 1. Tritium analysis system used in this study showing the oxidation apparatus.

eliminate spurious responses due to particulates. To eliminate the possibility of oil contamination, a molecular drag and diaphragm pump is used to evacuate the system.

The Femtotech ion gauge rejects pulse type radioactive events that effectively discriminate against radon and cosmic ray ionization. The initial background drift rate in the Femtotech was $0.002 \mathrm{nCi} / \mathrm{h}$ to $0.006 \mathrm{nCi} / \mathrm{h}$, but after 
exposure to the cells described in the paper, the drift rate increased, and could reach as high as $0.01 \mathrm{nCi} / \mathrm{h}$. In order to return to the baseline rate, it was necessary to clean the loop tubing and Femtotechs halfway through the study.

A hydrogen oxidation system was built as a backup test for tritium using a scintillation counter (Packard 1600). Calibration $\mathrm{D}_{2}$ gas with $25 \mathrm{nCi} /$ of tritium was used to test the two Femtotechs and the oxidation system. The two ionization systems agree to within $5 \%$ of each other while the scintillation results are within the experimental error $(0.3 \mathrm{nCi})$ of the Femtotechs.

The typical arrangement of the cell allows a wire to sit perpendicular to and a few millimeters above a circular plate. In operation, the plasma is adjusted so that it envelopes the whole wire and contacts the plate at a small spot. Typically, the plasma is light blue $\left(\mathrm{D}_{2}^{+}\right)$with areas of pink $\left(\mathrm{D}_{3}^{+}\right.$or $\left.\mathrm{D}^{+}\right)$. At high currents $(>5 \mathrm{~A})$, a bright pink electron channel forms that extends parallel to the wire from the base of the wire to the plate. Initially, the Pd wire is 25 to 30 $\mathrm{mm}$ in length and about one $\mathrm{mm}$ from the plate. The plate diameter is $3.0 \mathrm{~cm}$ or $1.8 \mathrm{~cm}$.

\section{PROCEDURE}

The procedure for a plasma run was to first fill the 3.1 liter loop with deuterium gas at 600 torr and obtain a measure of the initial background tritium concentration. With the loop drift rate measured, the deuterium was circulated through the cell to slowly hydride the sample. The pressure in the cell and the loop was then lowered to the operating pressure by pumping the excess deuterium out.

The wire was pulsed negatively, at $20 \mu \mathrm{s}$ at $50 \mathrm{~Hz}$, with currents between 2 and $5 \mathrm{~A}$, voltages that varied from 1500 to $2500 \mathrm{~V}$, and cell pressure of 300 torr. These conditions reduced the heating in the cell and maintained a cell to ambient temperature difference of less than $25^{\circ} \mathrm{C}$ to avoid gross dehydriding of the wire and plate. It appeared important to avoid a plasma condition that resulted in either a bright pink electron channel or arcing at the tip of the wire. After a few hours of plasma operation the voltage-current stabilized, presumably due to the formation of small cones (10-20 microns high) all over the surface of the wire. After 20 hours, palladium was visibly sputtered onto the plate. The sputter rate at 300 torr, $3.5 \mathrm{~A}$, was about $\sim 2 \mathrm{As}$. The cell pressure was monitored, and if it did not drop after 24 hours (indicating hydriding), then a small amount of $\mathrm{CO}_{2}(0.75 \%$ by vol $)$ was added, which would initiate hydriding.

At the end of a run the pressure was increased to 600 torr, the gas was circulated, and the system allowed to equilibrate for about 8 hours. If the reading was steady and $\mathrm{CO}_{2}$ was added, then the gas was circulated through the liquid nitrogen cold trap to collect any water and determine if any tritiated water was present. The system was then pumped out, the cell closed off, and fresh deuterium added to the system after a couple of flushes with either fresh deuterium or air. The difference between the fresh deuterium and the deuterium reading after exposure to the plasma was used as the measure of the tritium content. In cases where more than $10 \mathrm{nCi}$ were found, the palladium wire and plate were heated separately to over $250^{\circ} \mathrm{C}$ and the result admitted to the evacuated loop.

\section{RESULTS}

A total of 65 plasma wire experiments were performed, 12 of these were other than palladium wire and plate. Twenty experiments were run with multiple wires, usually 3 wires bundled together, and eight experiments used different thickness foils 25 to 125 microns thick. The balance of the tests were done with one 250 micron diameter wire and 250 micron thick plate. Three hydrogen plasma experiments were done with palladium plate and wire and two were done with platinum wire and plate. A summary of several background and foreground experiments is shown in Figure 2. The best experiment, produced $102 \mathrm{nCi}$.

Plasma runs 3 and 4 deserve some detailed explanation since these produced the most tritium. First, (see Figure 3) cell 3 was preheated in order to drive off any contaminants. The plasma was then started and the tritium generation rate was $0.15 \mathrm{nCi} / \mathrm{h}$. Near the end of the run, the cell was twice flushed with deuterium, which caused the total tritium (as detected by the Femtotech) to jump up. At the conclusion of the experiment the plate and wire (from plasma 3) were heated, insitu, and released another $5.4 \mathrm{nCi}$. In order to resolve whether the tritium was originating in the plate or wire, they were separately heated after plasma 4 . The wire released about $12.4 \mathrm{nCi}$ of tritium while the plate had no measurable $(<0.3 \mathrm{nCi})$ release.

A number of $\mathrm{Pt}$ and $\mathrm{Pd}$ controls were run with $\mathrm{D}_{2}$ or $\mathrm{H}_{2}$. Most of these are shown in Figure 2 in comparison with the foreground cells. In general, drift rates with the plasma on were in the 0.004 to $0.01 \mathrm{nCi} / \mathrm{h}$ range. Not enough 


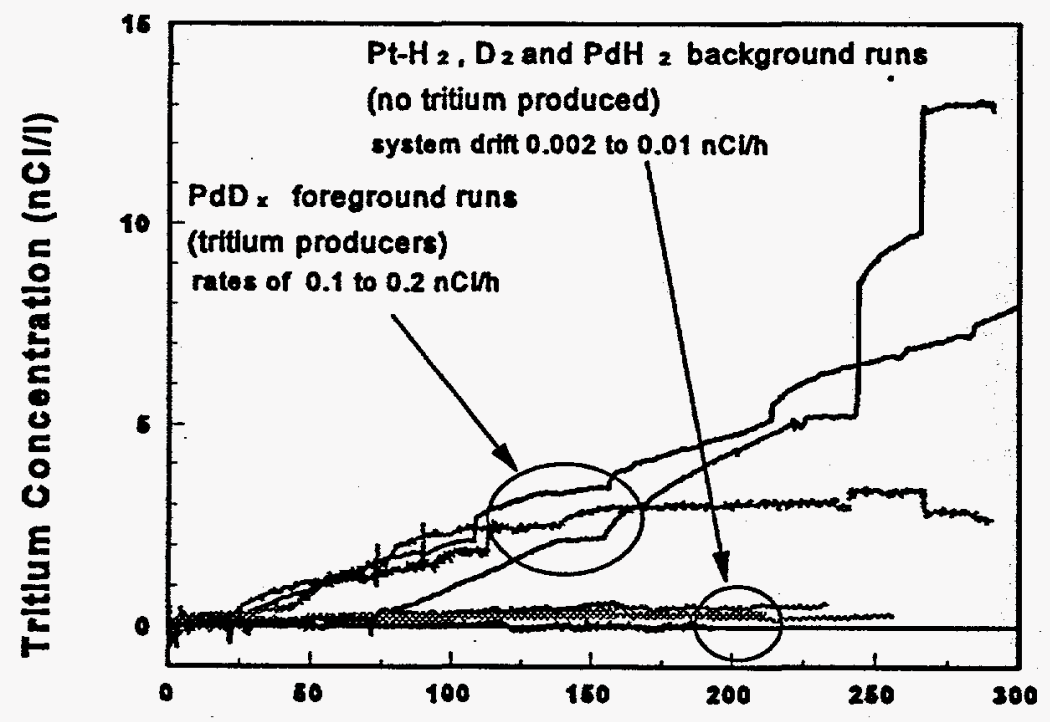

Time in Hours

Figure 2. Comparison of background and foreground results with a Pd wire-plate type plasma cell. A Pt wire-plate plasma and a flowing $D_{2}$ background is shown for comparison. hydrogen and platinum blank experiments have been run to definitely conclude that tritium production is confined to the palladium-deuterium system. We believe, however, that because the hydrogen and non-hydriding metal experiments are low or null, that the rather large results with palladium are unique. We also ran several hydride forming metals other than palladium. In the case of $\mathrm{Hf}$ and $\mathrm{Zr}$ it was difficult to maintain the plasma, so for most of the run the background drift rate is similar to the cell with $\mathrm{D}_{2}$ circulating $(\varangle 0.003 \mathrm{nCi} / \mathrm{h})$. Tungsten, vanadium, niobium, and nickel-deuterium were on for about 100 hours, but their rates were still very close to background $(0.007$ to $0.009 \mathrm{nCi} / \mathrm{h}$ ). Romodanov ${ }^{3}$ et. al. reported that $\mathrm{Nb}$ was more active than $\mathrm{W}, \mathrm{Zr}, \mathrm{Ta}$ or $\mathrm{Mo}$ in their gas discharge experiments. We also found small amounts of tritium in niobium $(1.1 \mathrm{nCi})$, and observed a small rate with nickelhydrogen $(0.012 \mathrm{nCi} / \mathrm{h})$. Both of these samples deserve further investigation.

The wire-plate plasma experiments have been very consistent but also very dependent on the exact batch of palladium that was used. We found that the batch, material and material condition are critical parameters. Our first batch of GF5140/6, for example, had an average rate of $0.4 \mathrm{nCi} / \mathrm{h}$, with several rates greater than $0.1 \mathrm{nCi} / \mathrm{h}$. Our second best results came from an arrangement with the second batch of the same wire in which three wires were bundled together. Their rates varied from 0.02 to $0.07 \mathrm{nCi} / \mathrm{h}$.

At $t$ h e conclusion of two of the experiments, about a third of the deuterium was oxidized and the heavy water and a control were submitted for scintillation counting. The results were 3400 to $213 \mathrm{dpm} / \mathrm{ml}$ and were in agreement (within experimental error) with the tritium activity calculated from

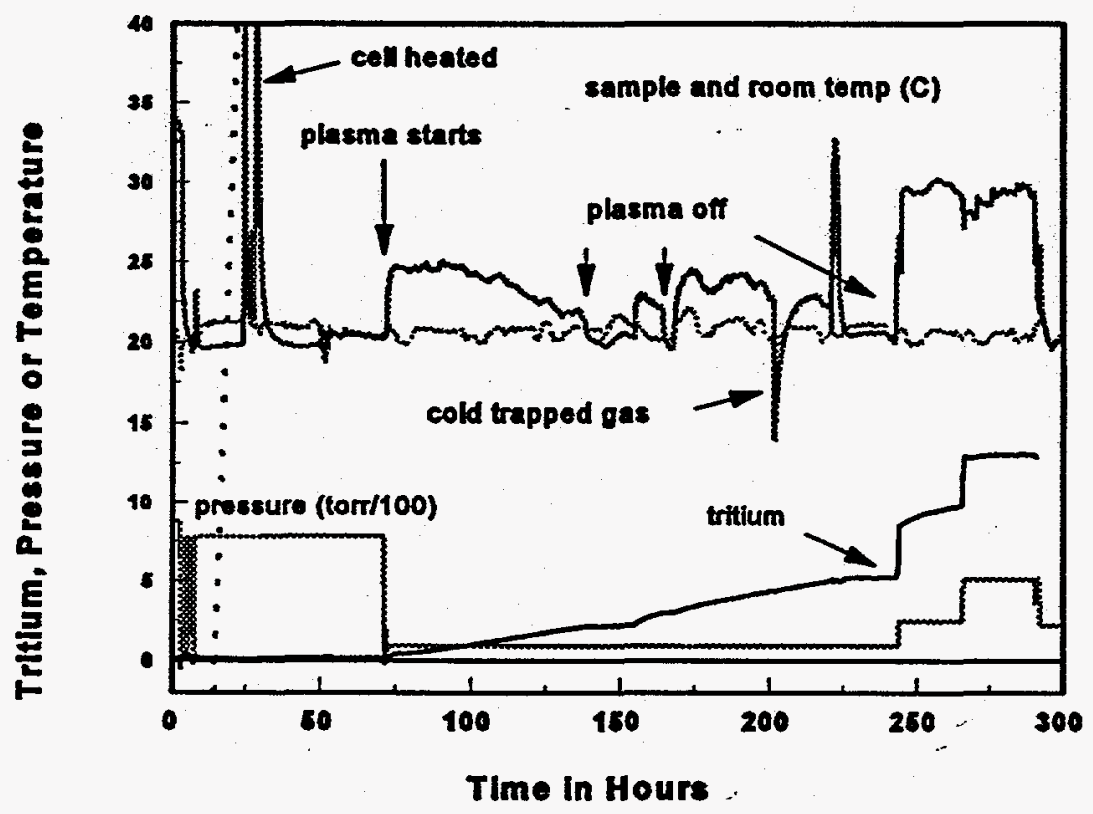

Figure 3. The cell temperature, ambient temperature, tritium concentration and pressure plotted to illustrate the operation of cell 3. When the sample temperature and the ambient temperature are close, the cell is off and the tritium concentration remains constant. When the cell temperature drops below ambient, the cold trap is activated; no significant decrease in the tritium level was noticed. 
the drop in reading of the Femtotech. Background activity from the $\mathrm{D}_{2}$ gas prepared by this method is about $39 \mathrm{dpm} / \mathrm{ml}$.

\section{DISCUSSION}

The basic premise that the detected ionizing material is tritium is indisputable because, (a) quantitative measurements agree with the scintillation counter, (b) the gas may be transported on a clean palladium bed between different ionization systems and produces an increased reading commensurate with the decrease in tritium concentration noted in the initial system, (c) as the pressure is decreased the tritium signal is seen to decrease (for dry gas) in a manner consistent with the calibration for a known level of tritium in deuterium and finally, (d) the signal shows no diminution over a two week time period, consistent with the half life of tritium.

Three types of contamination of the wire are possible; the first is just surface contamination due to atmospheric or liquid exposure to tritium, the second type might be a distributed impurity, and the third would be a spot contamination. To avoid surface contamination, we thoroughly clean and polish the palladium surface prior to each run. If it were still present, a surface contaminant would be immediately evident when the wire was introduced to the analysis loop and deuterided, but we have not seen evidence for this type of contamination. We attribute the residue and smoke seen from some of the wires to entrained lubricant due to drawing the wire. This lubricant tends to be drawn out and smeared throughout the length of the wire, which implies tritium contaminated oil should be detected in long sections of the wire. However, wires that showed obvious high levels of oil contamination did not show tritium, and we did not observe a large tritium signal when the wire was heated and the oil suddenly evolved. Similarly, the dark spots are present after simply heating the wire to $600^{\circ} \mathrm{C}$ but there is no evidence for tritium release at temperatures as high as $850^{\circ} \mathrm{C}$.

An indicator that the tritium originated in the cells is that the output was sensitive to the metallurgical condition of the palladium. Palladium wire annealed in air showed a lower output than as received wire. Likewise palladium wire stress relieved but not annealed showed a similar (about a factor of 3 ) reduction in output. This could be interpreted as a release of tritium if it was contamination, however, then the tritium would have been easily detected in the heating controls. In sample \#4, that showed significant tritium output post heating $\left(250^{\circ} \mathrm{C}\right)$ of the palladium wire released $12.4 \mathrm{nCi}$ of tritium. This amount of tritium would have been easily detected in the heating control of the same spool of wire $(10 \mathrm{~cm})$ taken from the next section of material. Furthermore, the tritium in the gas evolved from the wire during the post heating at $250^{\circ} \mathrm{C}$ was far $(5340 \mathrm{nCi})$ above the equilibrium tritium concentration $(31.4 \mathrm{nCi})$ in the gas after the run. The fact that such high concentrations can be left in the palladium suggests that the process is near but not at the surface. The pulse length is sufficient for the diffusion of 200 Angstroms (10 res pulse length) into the palladium. Then the tritium may be sputtered ( 1 to $2 \AA / s)$ out (along with the palladium) of the near surface layer by the energetic plasma. This would indicate that the tritium was in a 15 to 30 micron layer on the 250 micron in diameter wire. The fact that a significant amount of tritium shows up as (after the addition of $\mathrm{CO}_{2}$ ) $\mathrm{TDO}$ is also indicative of a near surface reaction. Dendrites and aspirates (up to 20 microns high) on the surface of the palladium have been suggested as possible tritium formation sites.

When palladium is hydrided it is stressed and, to some extent, work hardened. The wires after hydriding have always shown an increase in grain growth (to 50-100 microns) from the very fine (1-2 microns) microstructure initially observed with these materials. The observed reduction in stress relieved wires indicates that the dislocation density must play a very important role in the tritium production. However, since all as received wires were hard drawn but not all batches of wire showed production, there are other factors that are important, such as the purity and the hydriding.

The purity of the material varies from batch to batch, and within a batch sections of the wire are cleaner than other sections. Thus it could be that the lack of oil, iron or hydrogen impurities is critical or that there has to be an another atomic species present. We believe that the lack of oil or other impurities is important to help the material hydride efficiently. The key mechanism, however, may be associated with another impurity species that need be present only at the sub ppm level at the dislocations.

The importance of hydriding the palladium can be clearly observed in a plot (Figure 4) of tritium output versus time for a sample from batch Z0293 that weakly hydrided. The tritium evolution rate was at the background drift rate $(0.004 \mathrm{nCi} / 1)$. When $(0.75 \%$ by vol $) \mathrm{CO}_{2}$ was added to the system the tritium rate increased to a rate some 7.7 times the background drift rate. Coincident with the tritium increase, the deuterium pressure dropped indicating the palladium plate was hydriding. This decrease in pressure is more than can be accounted for if the $\mathrm{CO}_{2}$ is totally converted to $\mathrm{D}_{2} \mathrm{O}$. 

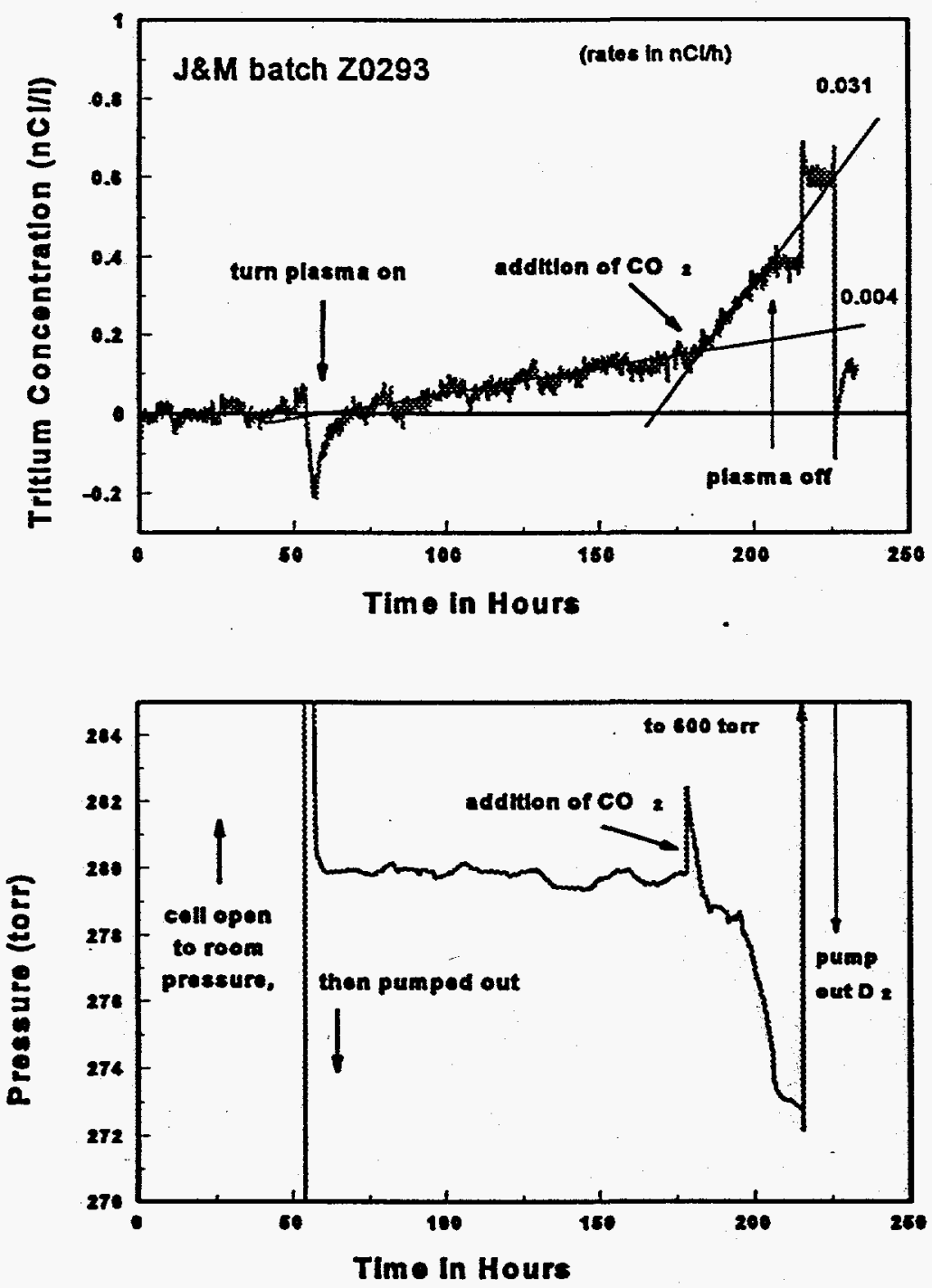

Figure 4. Tritium output from a cell that appeared to be a non producer until 2 torr of $\mathrm{CO}_{2}$ was added to the deuterium. This caused the plate (and perhaps wire) to hydride and a coincident rise in the tritium generation rate by a factor of $\sim 7$ was observed until the wire bent away from the plate.
We confirmed this with a platinum control cell in which the pressure only decreased by 2 torr. In another experiment where the pressure immediately dropped, indicating that the palladium had initially hydrided, the tritium generation rate was $\sim 0.02 \mathrm{nCi} / \mathrm{h}$ and an addition of $\mathrm{CO}_{2}$ did not change the rate of tritium production.

The $\mathrm{CO}_{2}$ may also make it feasible to run at lower pressures where a high loading is more difficult to achieve. An analysis of the ratio of tritiated water to tritium in the gas reveals that most (70\%) of the tritium remains in the gas. Additions of $\mathrm{CO}_{2}$ to $\mathrm{Pt}$ runs neither change the rate of drift (tritium) or exhibit large pressure decreases as shown in Figure 4. The $\mathrm{CO}_{2}$ and CO that is produced within the cell are known to be surface poisons that normally would not allow the palladium to hydride. However, in the

presence of a reactive energetic plasma the surface is cleaned of these materials and deuterium is allowed to disassociate on the surface and diffuse in. When the plasma ceases, the surface poison reabsorbs inhibiting deuterium from recombining on the surface.

\section{CONCLUSIONS}

We have found that the tritium output depends on the temperature, pressure and current applied to the cells. Yet, the tritium yield is most sensitive to the purity and metallurgical condition of palladium used in the experiments. Various tests for tritium contamination confirm that there is no initial tritium contamination in the powder, foil, wire or other materials used in this study. $\mathrm{CO}_{2}$ additions had a remarkable effect on the production of tritium by these cells and the effect seems to be related to and enhancement of the hydriding of the palladium.

It appears that very pure palladium is more effective than impure palladium in producing tritium. Based on our impurity analysis of the material we cannot identify a difference in concentration of a single impurity that is important to either include or exclude from the palladium. This is partially a morphological or metallurgical issue involving 
dislocations since we have seen a reduced output from annealed or stress relieved palladium when compared to as received palladium from the same batch. However, palladium that has been hydrided and dehydrided must always be annealed to reactivate it. The fact that most of the tritium is evolved promptly to the gas, yet significant amounts are found in the palladium suggest that the process is near but probably not at the surface.

\section{ACKNOWLEDGMENTS}

Many people were involved in a direct way with the experiments described here. Some of these were Ken Griechen, Roy Strandberg and Kane Fisher who were instrumental in the design and construction of the first few cells. Joe Thompson counted our tritiated water samples. Mike Hiskey and William Hutchinson were helpful in the analysis of contaminants in the vacuum system and on the samples.

\section{REFERENCES}

1. Tuggle, D. G., Claytor, T. N., and Taylor, S. F.; Tritium Evolution from Various Morphologies of Deuterided Palladium., Proceedings of the Fourth International Conference on Cold Fusion., December 6-9 1993, Maui, Hawaii., Ed. T. O. Passel, EPRI TR-104188-V1 Project 3170, July 1994, Volume 1, p7-2.

2. Bockris, J. O'M., Chien, C-C., Hodko, D., Minevski, Z, Tritium and Helium Production in Palladium Electrodes and the Fugacity of Deuterium Therein, Frontiers Science Series No. 4, Proceedings of the Third International Conference on Cold Fusion., October 21-25 Nagoya Japan., Ed. H. Ikegami, Universal Academy Press Tokyo Japan., 1993, p231.

3. Claytor, T. N., Tuggle, D. G., Taylor, S. F.; Evolution of Tritium from Deuterided Palladium Subject to High Electrical Currents, Frontiers Science Series No. 4, Proceedings of the Third International Conference on Cold Fusion., October 21-25 Nagoya Japan, Ed. H. Ikegami, Universal Academy Press Tokyo Japan., 1993, p217.

4. Cedzynska, K., Barrowes, S. C., Bergeson, H. E., Knight, L. C., and Will, F. W., Tritium Analysis in Palladium With an Open System Analytical Procedure, Fusion Technology, Vol. 20, No 1, 1991, p108, and private communication.

5. Romodanov, V., Savin, V., Skuratnik, Ya. Timofeev, Yu., Nuclear Fusion in Condensed Matter, Frontiers Science Series No. 4, Proceedings of the Third International Conference on Cold Fusion, October 21-25 Nagoya Japan, Ed. H. Ikegami, Universal Academy Press Tokyo Japan., 1993, p307. 